\title{
The Analysis of E-Prescribing System Acceptance in Hospitals Using SEM-PLS
}

\author{
Ensiwi Munarsih ${ }^{1}$, Yopi Rikmasari ${ }^{2}$ \\ \{ensiwi.munarsih@gmail.com ${ }^{1}$ \} \\ Institute of Pharmacy Bhakti Pertiwi Palembang ${ }^{1,2}$
}

\begin{abstract}
Electronic prescribing systems (e-prescribing) are designed to improve safety, quality, and health efficiency. The use of electronic systems was originally intended to save paper (paperless), but on its development, there are many benefits obtained from this system including reducing medication errors. The issues discovered during the use of the e-prescribing system served as the foundation for analyzing the use of the e-prescribing system in Palembang city hospitals. The test is conducted by examining the relationship between perceived ease of use and perceived usefulness and the intention to use variable. The purpose of this study was to determine user acceptance of an e-prescribing system using the Technology Acceptance Model (TAM). The Structural Equation Model was used to determine the influence of various factors (SEM). The evaluation data were collected through questionnaires distributed to e-prescribing system users. Seven out of ten indicators for perceived ease of use were significant, while all indicators for perceived usefulness were significant. According to the bootstrap estimation results, perceived ease of use and perceived usefulness both had an effect on intention to use. It can be concluded that the perceived ease of use and perceived utility of the electronic prescribing system used by several hospitals in Palembang have an effect on the intention to use.
\end{abstract}

Keywords: E-prescribing, technology acceptance model, structural equation model

\section{Introduction}

The advancement of information and communication technology has been quite rapid. It is quite helpful for humans in carrying out their activities, especially in the government sector which is commonly referred to as electronic government or commonly abbreviated as egovernment. Today's e-government has become a bridge towards the transformation of good governance, especially in implementing good public services for the community. The application of e-government will help achieve the effectiveness and efficiency of government performance in giving public services. The application of e-government is not limited to general public services such as demography, but also in the health sector. One of them is the use of electronic prescribing system (e-prescribing).

An Electronic prescribing system (e-prescribing) is designed to improve security, quality, and efficiency in health service. Initially, the use of electronic system was intended to reduce the use of paper (paperless), but in its development, many benefits have been obtained from this system, including reducing medication errors. Medication errors can occur anywhere in the chain of drug service for patients, from industry, reading of prescription, drug preparation, delivery to patients, to monitoring. Within each chain link there are several actions, each action has the potential as a source of error. The benefits of an e-prescribing include preventing reading 
errors, assisting doctors in determining e-prescribing preparations, helping doctors and pharmacists in their vigilance in determining drug administration (drug interactions, drug duplication, increasing drug purchase rates, shortening service time).

The issues discovered during the use of e-prescribing have been used to analyze the use of the e-prescribing system in Palembang hospitals. The purpose of this study was to determine user acceptance of an electronic prescribing system using the Technology Acceptance Model (TAM). The test was conducted by examining the effect of the variables Perceived Ease of Use and Perceived Usefulness on the variable Intention to Use. The influence of variables was determined using the Structural Equation Model (SEM) - Partial Least Squares method (PLS). SEM-PLS has made significant advancements in its application [1], and a wide variety of science fields have conducted research using SEM-PLS. SEM-PLS is a method that can overcome statistical problems including small sample size, overall model fit, and model specification errors [2]. The Application of the Technology Acceptance Model (TAM) in Testing the Acceptance Model for Regional Financial Information Systems is one of the studies that makes use of the TAM model [3]. In this study, testing was carried out using a linear regression model. [4] research results that the indirect effect shows that perceived usefulness affects behavioral intentions to use e-learning technology. According to research on the technology acceptance model analysis of the Shopee application in students [5], the factors of perceived usefulness, perceived ease of use, attitude, and intention to use all had a significant effect on students' acceptance of the Shopee application.

\section{Theoretical Framework}

\subsection{Conceptual model}

The Technology Acceptance Model, hereinafter referred to as TAM, is one of the adaptation theories of TRA (Theory of Reasoned Action) which was previously introduced by Ajzen and Fishbein in 1980 and proposed by Davis in 1989. TRA is a theory that explains a behavior is carried out by individuals who have the will or intention to carry out a certain activity. TAM is an analysis model for determining user behavior regarding technology acceptance, which means that TAM is an information system theory whose model is the process by which users come to accept and use technology, as illustrated in Figure 1 [6].

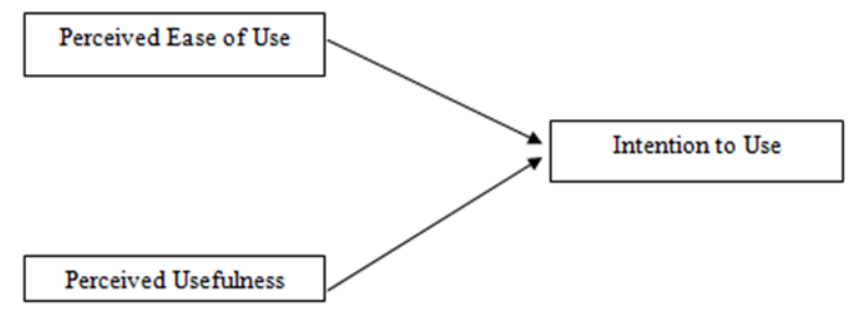

Fig. 1. Research Model

\subsection{Structural equation model}

SEM (Structural Equation Model) is a statistical technique for analyzing the relationship between latent constructs and their indicators, between latent constructs, and between latent 
constructs and each other. Structural Equation Model (SEM) is a technique with a combination of path analysis and regression analysis that allows researchers to test simultaneously a series of interrelated relationships between measured variables and latent constructs [7]. Structural Equation Modeling (SEM) is the data analysis technique used to thoroughly explain the relationship between variables in the study. SEM is a collection of statistical techniques that enables the simultaneous examination of a large number of relationships.

\subsection{Partial least square}

Due to its independence from the measurement scale, sample size, and residual distribution, partial least squares is an extremely powerful method of analysis [8]. The structural model employs the equation to denote the relationship between the independent latent variable (exogenous) and the dependent latent variable (endogenous)[9]:

$$
\eta=B \eta+\Gamma \xi+\zeta
$$

Where (eta) is the random variable for endogenous latent variables with a size of $\mathrm{m} x 1$, (xi) is the random variable for exogenous latent variables with a size of $\mathrm{n} \times 1, \mathrm{~B}$ is the coefficient matrix for endogenous latent variables with a size of mxm and the coefficient matrix for exogenous latent variables with a size of $\mathrm{n} \times 1$, which illustrates the relationship between and measuring $\mathrm{m} \times \mathrm{n}$, and (zet The latent variable structural model equation makes the following assumptions: ()$=0,()=0,()=0$, is uncorrelated with, and $((-)$ is a nonsingular matrix.

\subsection{Evaluation of the SEM-PLS model}

The evaluation of the PLS models include two phases, evaluation on measurement models and evaluation of structural models. Evaluation measurement of model is carried out with the following criteria:

- By focusing on the loading value, indicator reliability quantifies the number of indicator variants that can be explained by latent variables. If the loading value is less than 0.4 , the indicator must be removed from the model [10]

- Contract reliability, calculated through the value of $\rho^{\wedge}$ (composite reliability) and shows a value of more than 0.6

$$
\hat{\rho}=\frac{\left(\sum_{i=1}^{n} \widehat{\lambda}_{i}\right)^{2}}{\left(\sum_{i=1}^{n} \widehat{\lambda}_{i}\right)^{2}+\sum_{i=1}^{n} \operatorname{var}\left(\widehat{\varepsilon}_{l}\right)}
$$

- Convergent validity, checked using average variance extracted (AVE) with the formula

$$
A V E=\frac{\sum_{i=1}^{n} \hat{\lambda}_{i}^{2}}{\sum_{i=1}^{n} \hat{\lambda}_{i}^{2}+\sum_{i=1}^{n} \operatorname{var}\left(\widehat{\varepsilon}_{l}\right)}
$$

The minimum AVE value required to demonstrate adequate convergent validity is 0.5 Meanwhile, to evaluate the structural model, criteria [11] can be used.

- Using the following equation, R2 expresses the percentage of variance that can be explained by endogenous latent variables :

$$
R^{2}=\sum_{h=1}^{H} \quad \hat{\beta}_{j h} \operatorname{cor}\left(X_{j h}, Y_{j}\right)
$$


- Path coefficient, illustrates the power relationships between constructs

- The effect size f2, which indicates whether endogenous latent variables have a significant effect on endogenous latent variables, can be calculated as follows:

$$
f^{2}=\frac{R_{\text {include }}^{2}-R_{\text {exclude }}^{2}}{1-R_{\text {include }}^{2}}
$$

\subsection{Bootstrapping method}

Bootstrapping methods have been developed by Efron as a tool to help reduce non-mainstay related to improper use of the normal distribution and its use. In bootstrap, pseudo data is created using information and properties from the original data, so that the artificial data has similar characteristics to the original data [12]. In the bootstrap method, sampling is carried out with the return of the data sample (resampling with replacement) [3].

\section{Method}

\subsection{Sampling}

Data collection was carried out in Palembang by giving questionnaires to e-prescribing users in several hospitals in Palembang. The number of respondents on the instrument testing was 100 people with initial testing of the instrument was given to 35 respondents. A total of 110 questionnaires were distributed for the instrument testing, 4 questionnaires were not returned and 6 questionnaires were incomplete. The data of respondents' demography show in Table 1.

Table 1. Respondents' Demography

\begin{tabular}{llc}
\hline \multirow{3}{*}{ Gender } & \multicolumn{1}{c}{ Category } & Statistics (\%) \\
& Male & 47 \\
Education level & Female & 53 \\
& Diploma Degree & 56 \\
& Bachelor Degree & 15 \\
& Bachelor Degree/ profession & 17 \\
Occupation & Master's Degree/ specialist & 12 \\
& Doctor & 22 \\
& Specialist Doctor & 10 \\
& Physician & 10 \\
& Pharmacist & 15 \\
& Pharmacy technical staff & 40 \\
& Pharmaceutical administration & 3 \\
\hline
\end{tabular}

\subsection{Instrument}

The research questionnaire used a multi-item scale (Likert scale) adapted and developed from the Technology Acceptance Model (TAM) to assess the e-prescribing system's acceptance. All items were structurally evaluated using a Likert scale ranging from "Strongly Disagree" to 
"Strongly Agree," and several items were constructed using negative sentences. Before testing the instrument, an initial test was conducted on 35 respondents. The results of the respondents' responses were then used to carry out the instrument test.

\subsection{Data analysis}

In accordance with the research objectives, which are e-prescribing system acceptance analysis using the Technology Acceptance Model (TAM), path analysis and estimating model parameters, SEM-PLS is used with the aim of avoiding the limitations of using covariancebased SEM such as data distribution, small sample size, complex models with a big number of indicators, as well as model development and testing [13].

\section{Results and Discussions}

In the initial stage of the analysis, the researcher tested the normality of the data from the respondents' survey results. The results showed that the data were not normally distributed because the results indicated the significance value was smaller than the significance level that the researcher used i.e. 0.05. Prior to testing the hypothesis that the latent variables in the structural model are related, the first evaluation measurement model for verification indicators and latent variables can be further tested. The measurement / outer model analysis is carried out by taking into account the constructs used [14] In this study, a reflective construct was used, so that in analyzing the calculation results of Cronbach's Alpha, convergent validity, discriminant validity, and reliability were used [15].

A reliability indicator identifies the latent variable that accounts for the indicator's variance. When the loading value $(\lambda)$ is less than 0.4 , a reflective indicator should be eliminated (omitted) from the measurement model. The following are the results of the loading value $(\lambda)$ obtained after the loading factor was reduced to less than 0.4. The elimination result shows in Figure 2 that each occult variable can explain the variance of each indicator measuring more than $60 \%$. The next criteria which measure are the value of composite reliability and convergent validity (AVE). The result of the composite reliability value can be seen in Table 2, which indicates that the Composite Reliability (CR) of three latent variables is greater than 0.6. This means that all three measurement models are reliable because each contract variable is very well measured on predetermined indicators. The greater correlation between the indicators that comprise a construct, the more favorable the convergent validity value. The AVE value in Table 2 indicates that all three latent variables have a minimum AVE value of 0.5, indicating that the convergent validity measure is satisfactory or that the convergent validity criteria are met. Discriminant validity is the next test. Correlations between constructs and the AVE root were compared in this test. The result of correlation among latent variables shows in Table 3 and the AVE root value and discriminant validity for each latent variable show in Table 4. 


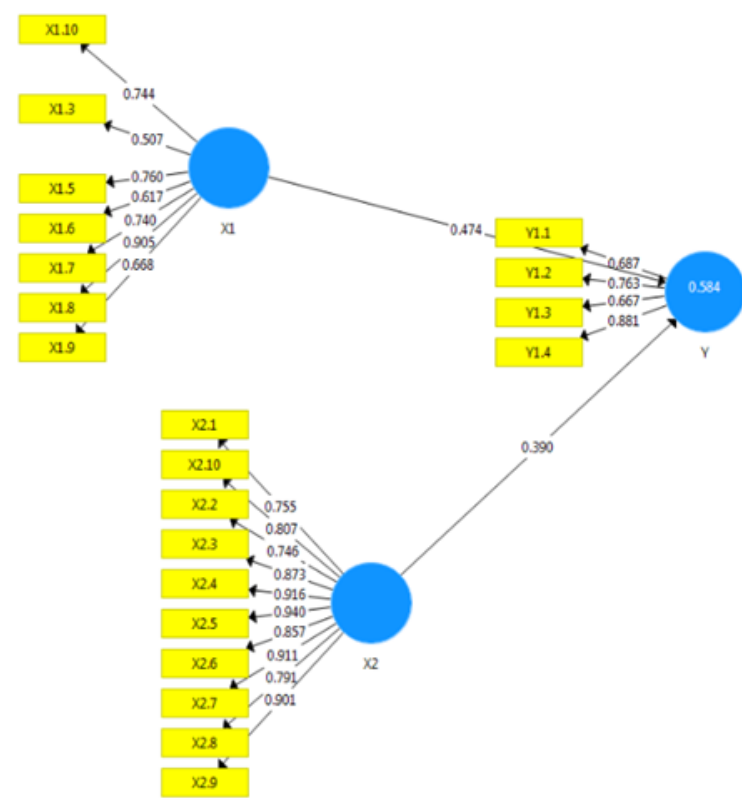

Fig. 2. Path Diagram with Loading Factor Value after Indicator Elimination

Table 2. Value of Composite Reliability and AVE of the Measurement Model

\begin{tabular}{llll}
\hline & Variable & Composite Reliability & AVE \\
\hline X1 & 0.877 & 0.511 & \\
X2 & 0.964 & 0.727 & \\
Y & 0.839 & 0.569 & \\
\hline
\end{tabular}

Table 3. Correlation among Latent Variables

\begin{tabular}{|c|c|c|c|}
\hline & $\mathrm{X} 1$ & $\mathrm{X} 2$ & Y \\
\hline $\mathrm{X} 1$ & 1 & 0.629 & 0.864 \\
\hline $\mathrm{X} 2$ & 0.629 & 1 & 0.750 \\
\hline Y & 0.864 & 0.750 & 1 \\
\hline
\end{tabular}

Table 4. AVE Root Value and Discriminant Validity for Each Latent Variable

\begin{tabular}{|c|c|c|}
\hline Variable & AVE Root & Discriminant Validity \\
\hline $\mathrm{X} 1$ & 0.715 & Qualify \\
\hline $\mathrm{X} 2$ & 0.852 & Qualify \\
\hline Y & 0.754 & Qualify \\
\hline
\end{tabular}

Table 5. Research Hypothesis Testing

\begin{tabular}{lllll}
\hline Hypothesis & Instruction & T-count & P-Value & Conclusion \\
\hline $\mathrm{H}_{1}$ & Perceived Ease of Use $\geq$ Intention to use & 4.371 & 0.000 & Accepted \\
$\mathrm{H}_{2}$ & Perceived Usefulness $\geq$ Intention to use & 3.352 & 0.001 & Accepted \\
\hline
\end{tabular}




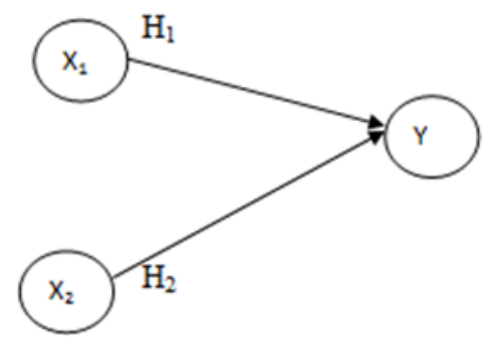

Fig. 3. Research Hypothesis

After testing the hypothesis, it is followed by an assessment of the coefficient of determination which aims to see the level of the relationship between latent variables / exogenous constructs to latent variables / endogenous constructs. The higher of the coefficient determination is the better relationship between the latent / construct variables.

Table 6. Determination Coefficient from Path Model

\begin{tabular}{lll}
\hline Latent Variable / Construct & R square & Decision \\
\hline Intention to Use & 0.584 & $\begin{array}{l}58.4 \% \text { variance of Intention to use is } \\
\text { typically due to Perceived Ease of use and } \\
\text { Perceived Usefulness }\end{array}$ \\
\hline
\end{tabular}

This study was conducted to see the acceptance of the e-prescribing system from its users. The model used in this study has been tested using PLS-SEM. PLS-SEM is used because it is suitable to be applied to complex models [13]. The PLS calculations reveal that exogenous variables, specifically Perceived Usefulness and Perceived Ease of Use, influence the measure of variance or predictive power of the endogenous latent variable path model Intention to Use by 58.4 percent (Table 6). In addition to examining the R-Square, the effect of endogenous variables on known exogenous variables was examined, as indicated by the effect size $\mathrm{f}^{2}$ in the following Table 7.

Table 7. f-Square Value of Each Exogenous Latent Variables

\begin{tabular}{lll}
\hline Variable & $f$-Square & Remark \\
\hline Perceived ease of used & 0.370 & Strong \\
Perceived Usefulness & 0.250 & Medium \\
\hline
\end{tabular}

\section{Conclusion}

The acceptance of the e-prescribing system in hospitals in Palembang is influenced by perceptions of usage on the ease of use of the system. In this case, the parties using the eprescribing system have the perception that the e-prescribing system is easy to use so that they can accept the e-prescribing system and continue to use it in their work. The acceptance of the e-prescribing system in hospitals in Palembang is also influenced by perceptions of the 
usefulness of the system. In this case, the user's perception of the usefulness of the e-prescribing system will affect the acceptance of the system. According to the bootstrap estimation results, the variables Perceived Ease of Use and Perceived Usefulness had a significant effect on Intention to Use $(\mathrm{p}=0.000)$. This indicates that both perceived ease of use and perceived usefulness influenced acceptance of the electronic prescribing system. Users of the e-prescribing system report that it is simple to use and beneficial to their work.

\section{Acknowledgments}

We would like to express our gratitude to the Ministry of Research, Technology, and Higher Education for funding this research, as well as to the Higher Education Service Institute (LLDIKTI) Region 2 for supervising the Research Institute. We would like to express our gratitude to Charitas Hospital Palembang and Charitas Hospital at Kilometer 7 Palembang for allowing us to conduct research on the e-prescribing system.

\section{References}

[1] Khan G.F, M. Sarstedt, W.-L. Shiau, J. F. Hair, C. M. Ringle., and Martin., "Internet Research," Methodol. Res. Partial least squares Struct. Equ. Model., no. 2018, pp. 1-45, 2018, doi: 10.4135/9780857020116.n103.

[2] M. Kargari and M. Shayan, "Identification of Parameters Affecting The Success of The Hospital Information System \& Presentation of A Model for User Satisfaction Improvement," J. Ind. Syst. Engginering, vol. 10, pp. 1-9, 2017.

[3] F. Sayekti and P. Putarta, "Penerapan Technology Acceptance Model (TAM) Dalam Pengujian Model Penerimaan Sistem Informasi Keuangan Daerah,” J. Manaj. Teor. dan Terap., vol. 9, no. 3, pp. 196-209, 2016.

[4] R. N. Rahmawati and M. Narsa, "Actual Usage Penggunaan E-Learning dengan Technology Acceptance Model (TAM)," vol. 6, no. 2, pp. 127-136, 2019.

[5] N. Fiyah, N. A. Mayangky, S. Hadianti, and D. Riana, "Analisis Technology Acceptance Model Pada Aplikasi Platform Perdagangan Elektronik Di Kalangan Mahasiswa,” J. Tek. Inform., vol. 12, no. 1, pp. 59-68, 2019, doi: 10.15408/jti.v12i1.10507.

[6] F. D. Davis, "A technology acceptance model for empirically testing new end-user information systems: Theory and results," Management, vol. Ph.D., no. May, p. 291, 1985, doi: oclc/56932490.

[7] Fatmawati E., "Technology Acceptance Model (TAM) untuk menganalisis penerimaan terasap sistem informasi perpustakaan," J. Iqra, 2015.

[8] H. Wold, ). Partial Least Square. In G. A. Marcoulides, Modern Methods For Business Research. New York: Psychology Press, 20123.

[9] W. W. Chin, The Partial Least Squares Approach to Structural Equation Modeling. Dalam G. A. Marcoulides, Modern Methods For Business Research. London: Lawrence Erlbaum Associates, 1998.

[10] V. E. Vinzi, W. W. Chin, J. Henseler, and H. Wang, Handbook of Partial Least Squares. Berlin: Springer., 2010.

[11] J. F. Hair, C. M. Ringle, and M. Sarstedt, "Partial Least Squares Structural Equation Modeling: Rigorous Applications, Better Results and Higher Acceptance," Long Range Plann., vol. 46, no. 12, pp. 1-12, 2013, doi: 10.1016/j.lrp.2013.01.001.

[12] Akalili S.N and Haryono, "Analisis Pengaruh Tenaga Penjualan(Marketer) Terhadap Kepuasan dan Pengaruh Kepuasan Terhadap Rekomendasi Di Perumahan ' $X$ ' Dengan Metode Structural Equation Modeling-Partial Least Square," pp. 1-8. 
[13] W. Chin, "Handbook of Partial Least Squares Concept, Methods, and Applications," Mol. Phys., vol. 115, 2017, doi: /10.1080/00268976.2016.1271155.

[14] I. Ghozali and H. Latan, Partial Least Squares Konsep, Teknik dan Aplikasi Menggunakan Program SmartPLS 3.0 untuk Penelitian Empiris. 2015.

[15] I. Santosa, Metode Penelitian Kuantitatif. Yogyakarta: Andi Publisher, 2018. 